\title{
An easily dismissed suspect of heart failure
}

\author{
Helder Santos, Hugo Miranda, Mariana Santos, Inês Grácio Almeida, \\ Lurdes Almeida
}

\author{
Cardiology Department, Centro Hospitalar Barreiro Montijo E.P.E., Barreiro, Portugal
}

\section{ARTICLE INFO}

Article history:

Submitted: 31. 3. 2020

Revised: 27. 5. 2020

Accepted: 4. 6. 2020

Available online: 21. 10. 2020

\section{Klúčová slová:}

Atriálny flutter

Kontriktívna perikarditída

Perikardiektómia

Transtorakálna echokardiografia

Zlyhanie srdca

\section{Keywords:}

Atrial flutter

Constrictive pericarditis

Heart failure

Pericardiectomy

Transthoracic echocardiography
SÚHRN

Konstriktívna perikarditída je zriedkavá patológia s niekol'kými možnými klinickými prejavmi. Jeho prítomnost' môže byt' zistená ako náhodné zistenie alebo ako primárna príčina iných prejavov alebo chorôb. Perikardiektómia je však jediným liečebným opatrením, môže však mat komplikácie a malo by sa vždy vziat do úvahy indikácia a riziko.

Predstavujeme prípad pacientky prijatej na typické príznaky flutteru predsiení a srdcového zlyhania. Etiologické vyšetrenie odhaluje zriedkavú prícinu srdcového zlyhania ako idiopatickú stahujúcu perikarditídu po niekol'kých vyšetreniach čakajúcich na perikardiektómiu.

(c) 2020, ČKS.

\begin{abstract}
Constrictive pericarditis is a rare pathology with several potential clinical manifestations. Its presence can be discovered as an incidental finding or as a primary cause of other manifestations or diseases. The pericardiectomy is the only curative measure; however, it could lead to some complications and we should always measure the pro and cons of the procedure.

We present a case of a female patient admitted for typical atrial flutter and heart failure symptoms. Etiology investigation revealed a rare cause of heart failure - idiopathic constrictive pericarditis - after several investigations' exams.
\end{abstract}

\section{Introduction}

Constrictive pericarditis (CP) is a rare etiology of heart failure with an unknown prevalence that can occur after any pericardial process. ${ }^{1} \mathrm{CP}$ is a chronic inflammatory process, characterized by scarring, thickened, fibrosis and pericardial calcification, which leads to an abnormal filling pattern of the ventricles, leading to impaired cardiac output and heart failure. ${ }^{2,3}$ Several etiologies can be associated with $\mathrm{CP}$, depending on the geographic regions. In developed countries post-surgical and idiopathic etiologies are the most frequent, ${ }^{2}$ on the other hand, in underdeveloped countries tuberculous pericarditis is the leading cause of $\mathrm{CP} .^{3}$ These pathologies can be characterized as chronic, subacute, transient and occult, ${ }^{3}$ being imperative the identification of the primary cause to try to prevent the development of CP. ${ }^{2}$ In most cases thickened pericardium was verified, nevertheless there were described cases of normal pericardium thickness at surgery, ${ }^{3}$ as well the disease manifestation after a pericardietomy. ${ }^{1}$

\section{Case report}

Fifty-eight-year-old woman, active smoking, referred to the emergency room for tachycardia on a routine electrocardiogram. History of 5 months of fatigue and dyspnea to ordinary activities, with progressive deterioration in the last month, associated with weight loss and episodic palpitations. Upon the physical examination, the patient presented jugular vein engorgement and peripheral edema. Admission electrocardiogram with typical atrial flutter at 150 of ventricular frequencies, without other findings (Fig. 1). Thoracic radiography showed only a small pericardium enhancement (Fig. 2). Abdominal echography revealed only moderate ascites. Blood work showed elevated

Address: Helder Santos MD, Cardiology Department, Centro Hospitalar Barreiro-Montijo, Avenida Movimento das Forças Armadas, 2834-003 Barreiro, Portugal, e-mail: helder33689@gmail.com

DOI: 10.33678/cor.2020.057 


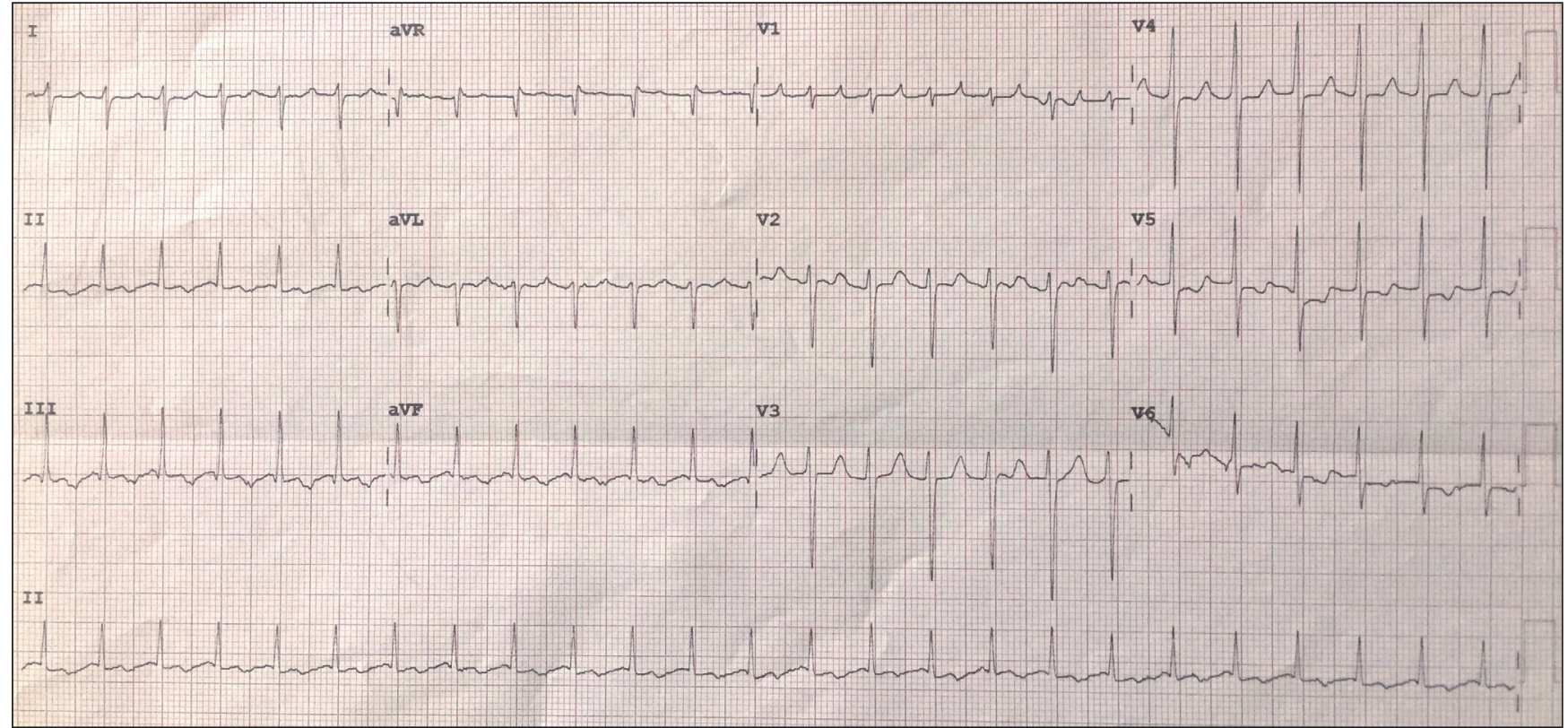

Fig. 1 - Electrocardiogram at admission that reveals a typical atrial flutter.

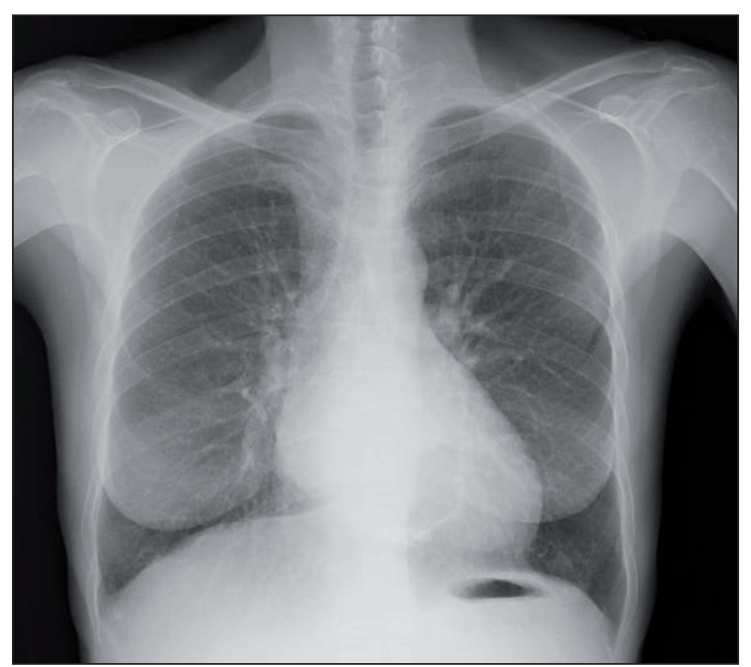

Fig. 2 - Thoracic radiography with tenues pericardium enhancement. liver enzymes, BNP of $230 \mathrm{pg} / \mathrm{ml}$, exclusion of infectious tuberculosis and autoimmune panel with isolated positive rheumatoid factor. Transthoracic echocardiography (TTE) at the emergency room showed a non-dilated and global left ventricle hypokinesia, with reduced left ventricular ejection fraction (LVEF, 29\%) and dilatation of the mitral valve ring in the genesis of moderate mitral regurgitation. Anticongestive and antiarrhythmic therapy was started with rhythm conversion and clinical improvement. Thoracic computed tomography scan revealed an extensive pericardial calcification (Fig. 3). Initiated disease modifying therapy with ACE inhibitors, beta-blockers and mineralocorticoid receptor antagonist medication, diuretic and anticoagulation, and 2 months later TTE reveal a preserved LVEF, pericardial calcification, moderate mitral regurgitation, grade III diastolic dysfunction, respiration-related ventricular septal shift, increased of the mitral E-wave velocity with an E/A of 2.76, the peak mitral E-wave decreases $36 \%$ with the inspiration, dilated
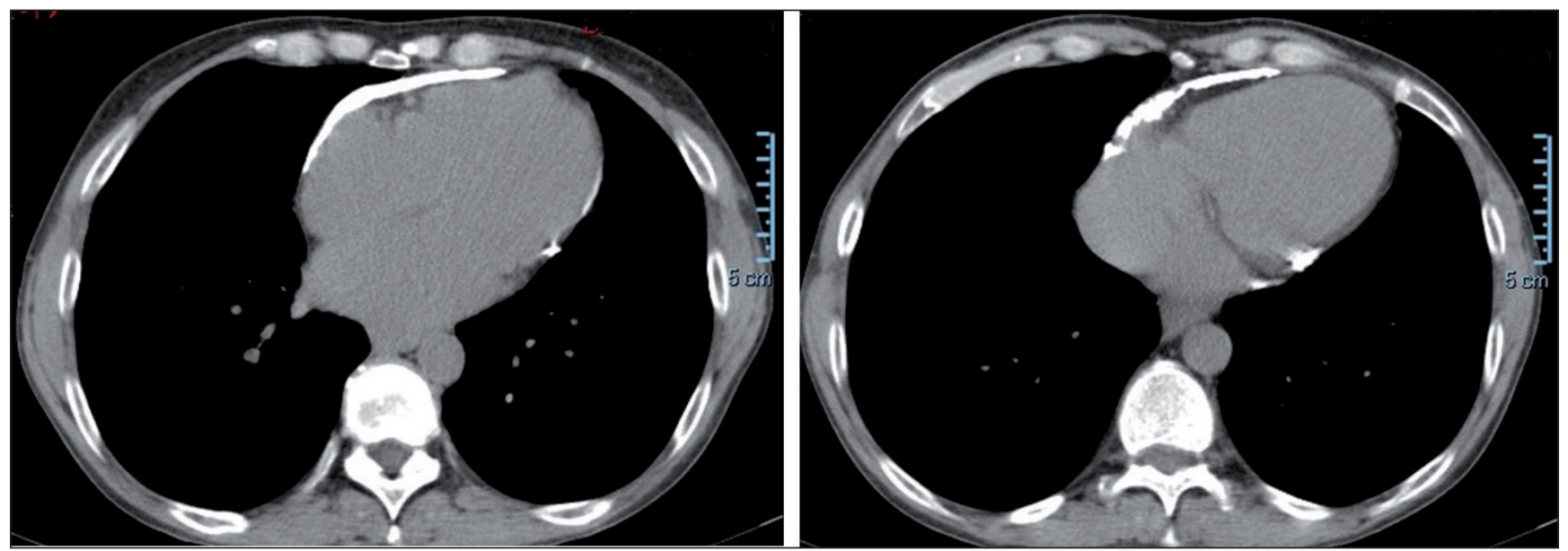

Fig. 3 - Thoracic computed tomography scan with an extensive pericardial calcification. 
inferior vena cava without respiratory variation. Cardiac MRI revealed a septal bounce and pericardial calcification - suggestive signs of constrictive pericarditis. Cardiac catheterization confirmed the presence of $\mathrm{CP}$. The patient was proposed to pericardiectomy. One-year follow-up revealed a persistent NYHA class I, however, the patient presented another episode of typical atrial flutter and an atrial flutter ablation was performed, without recurrence until the present date.

\section{Discussion}

Clinical suspicion of CP is crucial for its identification since there is not a specific clinical manifestation. Generally patient's presentation is with heart failure symptoms or symptoms secondary to a diminished cardiac output. Elevated jugular venous pressure is a frequent sign, and when associated with a suggestive clinical history should raise a high clinical suspicion. ${ }^{4}$

Chest radiography is recommended for all patients suspected of $C P,{ }^{1}$ yet not all the patients presented ring calcifications and its presence is not a direct signal of CP. ${ }^{5}$ Nonetheless, the presence of calcification is frequently not recognized by the physicians, only experienced and trained physicians are able to consider this type of pathology. As, in fact, occur in the case report, that even with a suggesting clinical history and the chest radiography just when was observed for an experienced physician a suspicion was considering.

Echocardiography is generally the first exam performed by the clinical physician to evaluate heart failure etiologies, with higher sensitivity and specificity for the diagnosis of CP. There are several direct and indirect signals suggesting the disease as pericardial thickening, respiratory variation of the mitral peak E velocity of $>25 \%$, dilated inferior vena cava with absent collapse, enhanced ventricular interaction, between others, that was recorded in our patient. ${ }^{3}$ It is an exam with an important role in the differential diagnosis, especially with restrictive cardiomyopathy. ${ }^{1,6}$ However, some patients do not present all the typical findings and the echocardiograph is not enough.

Computed tomography is the best exam to identify calcification, and in your case confirmed the suspicion, while a cardiac magnetic resonance is better to identify the hemodynamic perturbance, such as a septal bounce. Both exams are a class I recommendation in the recognized of CP. ${ }^{3}$

When there are still doubts, an invasive hemodynamic evaluation, that generally is not necessary, should be considered when doubts remaining, since allow a definitive confirmation the disease. The register of left and right ventricular diastolic pressure equalization, and a ventricular interference confirmed the diagnosis. ${ }^{1,7}$

Diuretic therapy is useful in the early stages to treat pulmonary and systemic congestion; nonetheless, its excess use can diminish an intravascular volume and consequently the cardiac output. Any other medications had a formal indication for CP therapy. Pericardiectomy is the definite treatment, however, the moment of its performance is not well established, since patients can remain in NYHA class I several years. Nevertheless, generally after the procedure a rapid hemodynamic and symptomatic improvement is registered, yet the surgical procedure has a higher mortality rate. ${ }^{2}$

\section{Conclusions}

The literature had little cases of CP presented with an arrhythmia, and the knowledge of the authors is the first report of atrial flutter with $C P$. Still, independently of the arrhythmia type, all of them promoted a ventricular dyssynchrony and considering the diastolic dysfunction there is a higher probability to induce symptoms, especially heart failure symptoms, as our patient.

The case highlights the importance of CP suspicion to establish a relationship between the clinical data, clinical evaluation and the several cardiac methods that we dispose. An early diagnosis is imperative, since allow to a premature intervention with lower rates of mortality, complications and NYHA class.

\section{Conflict of interest}

The authors declare no conflict of interest.

\section{Funding}

None.

\section{Consent for publication}

The written consent for publication from the patient was obtained.

\section{References}

1. Adler $Y$, Charron $P$, Imazio M, et al. 2015 ESC Guidelines for the diagnosis and management of pericardial diseases: the Task Force for the Diagnosis and Management of Pericardial Diseases of the European Society of Cardiology (ESC) Endorsed by: The European Association for Cardio-Thoracic Surgery (EACTS). Eur Heart J 2015;36:2921-2964.

2. Matshela MR. Constrictive pericarditis: prevention and treatment. European Society of Cardiology 2017;15(24).

3. Klein AL, Abbara S, Agler DA, et al. American Society of Echocardiography clinical recommendations for multimodality cardiovascular imaging of patients with pericardial disease: endorsed by the Society for Cardiovascular Magnetic Resonance and Society of Cardiovascular Computed Tomography. J Am Soc Echocardiography 2013;26:965-1012. e15.

4. Kyriakakis C, Herbst P, Doubell A. Constrictive pericarditis prevalence, causes and clinical presentation. European Society of Cardiology 2017;15:1-8.

5. Ling LH, Oh JK, Breen JF, et al. Calcific constrictive pericarditis: is it still with us? Annal Internal Medicine 2000;132:444-450.

6. Silva D, Sargento L, Varela MG, et al. Pericardite constritivanovos métodos no diagnóstico de uma velha doença: a propósito de um caso clínico. Revista Portuguesa de Cardiologia 2012;31:677-682.

7. Troughton RW, Asher CR, Klein AL. Pericarditis. Lancet 2004;363:717-727. 